\title{
Hubungan Skor GCS dengan Fungsi Kognitif pada Pasien Cedera Otak Traumatik di IGD RSUD Ulin Banjarmasin
}

\author{
Apidha Kartinasari*), Kenanga M. Sikumbang ${ }^{* *}$, Fakhrurrazy $\left.^{* * *}\right)$ \\ ${ }^{*}$ Fakultas Kedokteran Universitas Lambung Mangkurat Banjarmasin, ${ }^{* *}$ Departemen Anestesiologi dan Terapi \\ Intensif, Fakultas Kedokteran, Universitas Lambung Mangkurat/RSUD Ulin Banjarmasin, ${ }^{* * *}$ Departemen \\ Penyakit Syaraf, Fakultas Kedokteran, Universitas Lambung Mangkurat, RSUD Ulin Banjarmasin.
}

\begin{abstract}
Abstrak
Latar Belakang dan Tujuan: Cedera Otak Traumatik (COT) merupakan cedera yang mempengaruhi tingkat kesadaran serta fungsi neurologis. Pemeriksaan GCS dilakukan untuk mengkategorikan keparahan yang terjadi pada COT. Kondisi pasca COT dapat menyebabkan terjadinya penurunan fungsi kognitif karena terjadi kerusakan pada sel-sel otak serta vaskularisasinya. Tujuan penelitian ini untuk mengetahui apakah terdapat hubungan antara skor GCS dengan pemeriksaan fungsi kognitif menggunakan Mini Mental State Examination (MMSE) dan Clock Drawing Test (CDT) pada pasien COT di Instalasi Gawat Darurat (IGD) RSUD Ulin Banjarmasin.

Subjek dan Metode: Penelitian ini bersifat observasional analitik dengan pendekatan cross sectional. Sebanyak 48 sampel didapatkan secara consecutive sampling.

Hasil: Pada COT ringan terdapat 2 pasien (10\%) mengalami penurunan fungsi kognitif, COT sedang 15 pasien $(83,3 \%)$, dan COT berat 9 pasien $(90 \%)$. Analisis data menggunakan uji Chi-Square dengan tingkat kepercayaan 95\% menunjukkan penurunan fungsi kognitif seiring dengan semakin beratnya COT $(p=0,000)$. Simpulan: Terdapat hubungan antara skor GCS dengan fungsi kognitif menggunakan MMSE dan CDT pada pasien COT.
\end{abstract}

Kata kunci: Cedera Otak Traumatik, GCS, Fungsi Kognitif, Mini Mental State Examination, Clock Drawing Test

JNI 2020; 9 (1): 1-7

\section{Relationship between Glasgow Coma Scale (GCS) Score with Cognitive Function in Traumatic Brain Injury Patient at Emergency Department of Ulin General Hospital Banjarmasin}

\begin{abstract}
Background and Objective: Traumatic Brain Injury (TBI) is an injury that affects the level of consciousness and neurological function. GCS examination is done to categorize the severity that occurs in TBI. Conditions after traumatic brain injury cause cognitive function impairment due to damage of brain cells and its vascularization. Analyze the relationship between GCS scores and cognitive function test using MMSE and CDT in TBI patients. Subject and Method: This study was observational analytic in design with a cross sectional approach. A total of 48 samples were obtained by consecutive sampling.

Result: In mild TBI there were 2 patients (10\%) experienced decrease in cognitive function, moderate TBI was 15 patients $(83.3 \%)$, and 9 patients $(90 \%)$ in severe TBI. Data analysis used Chi-Square test with $95 \%$ confidence level which showed a decrease in cognitive function along with the increasing severity of TBI $(p=0.000)$.

Conclusion: There was a relationship between GCS scores and cognitive function using MMSE and CDT in TBI patients.
\end{abstract}

Key words: TBI, GCS, Cognitive Function, Mini Mental State Examination, Clock Drawing Test

JNI 2020; 9 (1): 1-7 


\section{Pendahuluan}

Cedera otak traumatik (COT) adalah permasalahan dunia yang penting secara medis, kesehatan masyarakat, dan sosial. COT merupakan penyebab utama kecacatan jangka panjang, mortalitas dan morbiditas pada usia muda. Berdasarkan data dari Centers for Disease Control and Prevention (CDC), terdapat sekitar 2,8 juta orang yang telah dirawat pada tahun 2013 akibat COT di Amerika Serikat. Hasil Riset Kesehatan Dasar (Riskesdas) di Indonesia tahun 2013 menyatakan bahwa insidensi COT terjadi rata-rata sekitar $0,4 \%$ dari seluruh jenis cedera. Kejadian COT di Indonesia dengan Case Fatality Rate (CFR) menunjukkan bahwa 100.000 jiwa meninggal dunia pada tahun 2013. Insidensi di Kalimantan Selatan sendiri telah mencapai 0,3\% kejadian COT dari seluruh jenis cedera. ${ }^{1}$

Pasien yang datang dengan COT diklasifikasikan berdasarkan tingkat keparahan cederanya menjadi ringan, sedang, dan berat berdasarkan skor Glasgow Coma Scale (GCS). Cedera otak traumatik ringan jika skor GCS 13-15, cedera otak traumatik sedang jika skor GCS 9-12, sedangkan cedera otak traumatik berat bila skor GCS 3-8. ${ }^{2}$ Gangguan pasca COT meliputi keterampilan motorik, kecepatan pemrosesan, perhatian, ketepatan kata, memori, keterampilan sosial, dan fungsi eksekutif. Gangguan kognitif yang terjadi setelah COT sering dikaitkan dengan tingkat keparahan cedera kepala. Fungsi kognitif tidak hanya mengalami kerusakan pada proses COT saja, namun bisa juga terjadi pada proses hilangnya neuron pada penyakit Alzheimer atau bisa juga terjadi pada proses penuaan yang normal saja terjadi. Selain itu, kerusakan pada sel glia dan mikrovaskular juga telah terbukti berperan penting pada proses gangguan fungsi kognitif. Proses hilangnya neuron/kematian neuron, cedera aksonal difus, perdarahan mikro, serta gangguan Blood Brain Barrier (BBB) dipercaya berperan penting dalam perkembangan gangguan kognitif setelah terjadinya cedera otak traumatik. ${ }^{3,4}$

Pada penelitian yang dilakukan di RSUD Achmad Pekanbaru menyatakan bahwa tidak ada hubungan antara status fungsi kognitif dengan keparahan COT. Gangguan kognitif kemungkinan disebabkan oleh letak atau lokasi trauma yang mengenai bagian kepala seperti infark atau lesi pada otak yang mengatur bagian kognitif. Lesi intrakranial sendiri dapat diklasifikasikan sebagai fokal atau difusa, walau kedua bentuk cedera ini sering terjadi bersamaan. ${ }^{5}$ Namun berbeda dengan penelitian di New Delhi yang menyatakan bahwa, terdapat disfungsi kognitif sedang pada kelompok pasien COT dengan skor GCS awal 9-10, dan tidak ada disfungsi kognitif pada kelompok pasien COT dengan skor GCS awal 11-12. Semakin tinggi skor GCS, maka semakin kecil resiko penurunan fungsi kognitif. ${ }^{6}$

Gangguan kognitif yang muncul selama atau secara langsung setelah terapi COT dilaporkan sering terjadi. Beberapa studi evaluasi memfokuskan pada fungsi neurologis klinis atau instrumen neuropsikologis seperti Mini Mental State Examination (MMSE). Mini Mental State Examination (MMSE) terdiri dari 11 pertanyaan yang terbagi menjadi dua bagian. Bagian pertama membahas orientasi, perhatian, dan memori, sedangkan bagian kedua yakni verbal dan keterampilan tertulis. Skor maksimum adalah 30 , sedangkan skor $\leq 23$ adalah indikasi penurunan fungsi kognitif. ${ }^{7}$ Tes kognitif lain yang sering digunakan adalah Clock Drawing Test (CDT). Banyak jenis uji CDT, namun tidak ada konsensus yang menjelaskan tentang metode yang paling tepat untuk digunakan. Metode oleh Shulman merupakan salah satu sistem penilaian yang paling banyak digunakan saat ini. Terdiri dari skor 0 sampai 5. Skor 4 hingga 5 merupakan batas keadaan normal. Sedangkan skor $\leq 3$ merupakan indikasi penurunan fungsi kognitif. ${ }^{8}$ Berdasarkan uraian tersebut, maka peneliti tertarik melakukan penelitian untuk menganalisis hubungan skor GCS dengan fungsi kognitif menggunakan MMSE dan CDT pada pasien COT di IGD RSUD Ulin Banjarmasin.

\section{Subjek dan Metode}

Penelitian ini merupakan penelitian observasional analitik dengan rancangan cross sectional. Sampel penelitian adalah 48 pasien yang telah memenuhi kriteria inklusi dan eksklusi dan telah 
menandatangani lembaran informed consent. Kriteria inklusi sampel penelitian adalah sebagai berikut: Pasien dengan usia 18-60 tahun; Pasien COT dengan gambaran CT-Scan EDH, SDH, $\mathrm{ICH}$, atau kombinasi; Pasien COT tunggal (tidak ada trauma berat pada bagian tubuh lain). Kriteria eksklusi sampel penelitian adalah pasien COT dengan riwayat gangguan psikiatrik yang diketahui dengan alloanamnesis. Peneliti akan melakukan observasi dengan cara menilai skor GCS setelah pasien distabilkan saat masuk IGD untuk menentukan tingkat keparahan COT, yang dikategorikan menjadi COT ringan (1315), COT sedang (9-12), dan COT berat (3-8), selanjutnya akan ditunggu hingga hari ke-5 untuk dilakukan penilaian fungsi kognitif pasien menggunakan MMSE dan CDT. Pasien yang koma atau belum sadar sepenuhnya pada hari ke-5 akan mendapatkan skor 0 pada penilaian fungsi kognitifnya, baik MMSE maupun CDT. Kemudian data yang terkumpul akan ditabulasi dan dianalisis hasilnya menggunakan uji ChiSquare.

\section{Hasil}

Telah dilakukan penelitian mengenai hubungan tingkat keparahan cedera kepala berdasarkan skor GCS dengan fungsi kognitif pasien COT di RSUD Ulin Banjarmasin pada bulan Juli-September 2018. Berdasarkan penelitian ini (Tabel 1) didapatkan bahwa pasien COT di IGD RSUD Ulin Banjarmasin pada bulan Juli-September 2018 didominasi oleh pasien usia 18-40 tahun yakni lebih banyak terjadi pada usia dewasa muda. Pada penelitian ini (Tabel 1) didapatkan pasien COT yang terbanyak adalah laki-laki dibandingkan perempuan. Berdasarkan distribusi kejadiannya (Tabel 1) didapatkan bahwa COT di RSUD Ulin Banjarmasin didominasi oleh COT ringan yang paling banyak terjadi, kemudian diikuti COT sedang dan COT berat. Mekanisme pada penelitian ini (Tabel 1) paling banyak terjadi akibat kecelakaan lalu lintas, terutama kecelakaan lalu lintas roda 2. Selain itu, didapatkan juga mekanisme penyebab lain pada penelitian ini, yakni terjatuh. Pada penelitian ini (Tabel 1) juga didapatkan bahwa terapi konservatif merupakan terapi terbanyak yang diberikan pada pasien COT.
Tabel 1. Hubungan Skor GCS dengan Fungsi Kognitif Pasien Cedera Otak Traumatik di IGD RSUD Ulin Banjarmasin.

\begin{tabular}{lcc}
\hline Karakteristik & $\mathrm{n}$ & $\%$ \\
\hline Usia (tahun) & & \\
$18-40$ & 28 & 58 \\
$41-60$ & 20 & 42 \\
Jenis Kelamin & & \\
$\quad$ Laki-laki & 37 & 77 \\
$\quad$ Perempuan & 11 & 23 \\
Distribusi COT & & \\
$\quad$ Ringan & 20 & 41,7 \\
Sedang & 18 & 37,5 \\
$\quad$ Berat & 10 & 20,8 \\
Mekanisme & & \\
KLL roda 4 & 4 & 8,3 \\
KLL roda 2 & 33 & 68,8 \\
Terjatuh & 11 & 22,9 \\
Terapi & & \\
Konservatif & 34 & 70,8 \\
$\quad$ Operatif & 14 & 29,2 \\
Fungsi Kognitif & & \\
$\quad$ Normal & 22 & 45,8 \\
Menurun & 26 & 54,2 \\
Jumlah Subjek Penelitian & 48 & 100 \\
*COT; Cedera Otak Traumatik, KLL; Kecelakaan Lalu \\
Lintas.
\end{tabular}

Berdasarkan (Tabel 1) pada pemeriksaan fungsi kognitif didapatkan bahwa 26 pasien COT $(54,2 \%)$ mengalami penurunan fungsi kognitif.

Berdasarkan penelitian ini (Tabel 2) didapatkan bahwa penurunan kognitif menggunakan MMSE paling banyak pada atensi dan kalkulasi, serta orientasi. Dilakukan uji statistik dengan uji $\mathrm{Chi}$ Square (Tabel 3) dan diperoleh nilai $\mathrm{p}=0,000$. Dengan demikian, hipotesis yang diajukan dapat diterima bahwa terdapat hubungan tingkat keparahan cedera menggunakan skor GCS dengan fungsi kognitif menggunakan MMSE pada pasien COT di IGD RSUD Ulin Banjarmasin. Kemudian dilakukan uji statistik dengan uji ChiSquare (Tabel 4) diperoleh nilai $\mathrm{p}=0,000$. Dengan demikian, hipotesis yang diajukan dapat diterima bahwa terdapat hubungan skor GCS dengan 
Tabel 2. Distribusi Penurunan Komponen MMSE menurut Variabel yang Diteliti

\begin{tabular}{|c|c|c|c|c|c|c|c|c|c|c|}
\hline \multicolumn{11}{|c|}{ MMSE } \\
\hline \multirow[t]{2}{*}{ Variabel } & \multicolumn{2}{|c|}{ Orientasi } & \multicolumn{2}{|c|}{ Orientasi } & \multicolumn{2}{|c|}{ Atensi \& Kalkulasi } & \multicolumn{2}{|c|}{ Mengingat Kembali (Recall) } & \multicolumn{2}{|l|}{ Bahasa } \\
\hline & $\mathrm{n}$ & $\%$ & $\mathrm{n}$ & $\%$ & $\mathrm{n}$ & $\%$ & $\mathrm{n}$ & $\%$ & $\mathrm{n}$ & $\%$ \\
\hline \multicolumn{11}{|c|}{ Distribusi COT } \\
\hline Ringan & 2 & 7,7 & - & - & 2 & 7,7 & 2 & 9,5 & 2 & 6 \\
\hline Sedang & 15 & 57,7 & 11 & 57,9 & 15 & 57,7 & 10 & 47,6 & 14 & 56 \\
\hline Berat & 9 & 34,6 & 8 & 42,1 & 9 & 34,6 & 9 & 42,9 & 9 & 36 \\
\hline Total & 26 & 100 & 19 & 100 & 26 & 100 & 21 & 100 & 25 & 100 \\
\hline \multicolumn{11}{|l|}{ Jenis Kelamin } \\
\hline Laki-laki & 20 & 76,9 & 14 & 73,7 & 20 & 76,9 & 17 & 81 & 19 & 76 \\
\hline Perempuan & 6 & 23,1 & 5 & 26,3 & 6 & 23,1 & 4 & 19 & 6 & 24 \\
\hline Total & 26 & 100 & 9 & 100 & 26 & 100 & 21 & 100 & 25 & 100 \\
\hline \multicolumn{11}{|l|}{ Usia (tahun) } \\
\hline $18-40$ & 13 & 50 & 11 & 57,9 & 13 & 50 & 12 & 57,1 & 12 & 48 \\
\hline $41-60$ & 13 & 50 & 8 & 42,1 & 13 & 50 & 9 & 42,9 & 13 & 52 \\
\hline Total & 26 & 100 & 19 & 100 & 26 & 100 & 21 & 100 & 25 & 100 \\
\hline
\end{tabular}

Tabel 3. Hubungan Skor GCS dengan Fungsi Kognitif Menggunakan MMSE pada Pasien Cedera Otak Traumatik

\begin{tabular}{llll}
\hline GCS & $\begin{array}{l}\text { MMSE } \\
\text { Normal }\end{array}$ & $\begin{array}{l}\text { MMSE } \\
\text { menurun }\end{array}$ & Nilai $\mathrm{p}$ \\
\hline COT ringan & $18(90 \%)$ & $2(10 \%)$ & \\
COT sedang & $3(16,7 \%)$ & $15(83,3 \%)$ & 0,000 \\
COT berat & $1(10 \%)$ & $9(90 \%)$ & \\
\hline
\end{tabular}

Tabel 4. Hubungan Skor GCS dengan Fungsi Kognitif Menggunakan CDT Pada Pasien Cedera Otak Traumatik

\begin{tabular}{llll}
\hline GCS & $\begin{array}{l}\text { CDT } \\
\text { Normal }\end{array}$ & CDT menurun & Nilai p \\
& & & \\
\hline COT ringan & $18(90 \%)$ & $2(10 \%)$ & \\
COT sedang & $3(16,7 \%)$ & $15(83,3 \%)$ & 0,000 \\
COT berat & $1(10 \%)$ & $9(90 \%)$ & \\
\hline
\end{tabular}

fungsi kognitif menggunakan CDT pada pasien COT di IGD RSUD Ulin Banjarmasin.

\section{Pembahasan}

Pada penelitian ini membagi usia menjadi dua kategori menurut Hurlock yaitu usia 18-40 tahun dan 41-60 tahun. Hasilnya didapatkan bahwa pasien COT di IGD RSUD Ulin Banjarmasin didominasi oleh pasien usia 18-40 tahun. Kejadian COT paling banyak terjadi pada usia 14 hingga 30 tahun, dan menurun di usai 30 tahun hingga 60 tahun. Tingginya angka kejadian kecelakaan pada kelompok usia aktif dan produktif dapat dikaitkan dengan tingkat mobilitas yang tinggi dan perkembangan kejiwaan, dimana usia remaja hingga dewasa muda perkembangan jiwanya belum stabil sehingga belum dapat mengendalikan emosi dirinya. Keadaan ini menyebabkan sikap yang kurang waspada, sehingga seringkali kurang memperhatikan keselamatan dirinya sendiri maupun orang lain dalam mengemudikan kendaraan. ${ }^{9}$

Penelitian ini menunjukkan bahwa pasien COT yang terbanyak adalah laki-laki dibandingkan perempuan. Hasil penelitian ini tidak berbeda dengan penelitian yang dilakukan di RSUP Prof. Dr. R. D. Kandou Manado periode 2012-2013, bahwa pasien COT berjenis kelamin laki laki sebanyak $76 \%$ dan perempuan sebanyak $24 \%$. Hal ini disebabkan karena laki-laki memiliki 
aktifitas yang lebih tinggi dibandingkan dengan perempuan sehingga kontaminasi denga berbagai faktor resiko penyebab penyakit pun lebih tinggi pada laki-laki. Pada kejadian kecelakaan lalu lintas, aspek jenis kelamin juga menjadi bahan pertimbangan terhadap interpretasi tingginya kejadian kecelakaan lalu lintas terutama dijalan raya yang didominasi oleh laki-laki. ${ }^{10}$

Distribusi COT di IGD RSUD Ulin Banjarmasin pada penelitian ini berjumlah 48 pasien dengan didominasi oleh COT ringan, kemudian diikuti COT sedang dan COT berat. Hal ini sesuai dengan Konsensus PERDOSSI (2006) yang menyatakan bahwa dari 777 pasien COT pada tahun 2005 di Rumah Sakit Cipto Mangunkusumo Jakarta, sebanyak 434 pasien $(56 \%)$ mengalami COT ringan, 315 pasien ( $40 \%$ ) mengalami COT sedang, dan 28 pasien $(4 \%)$ mengalami COT berat. ${ }^{11}$ Satu pada penelitian juga menyatakan bahwa pasien COT di Rumah Sakit Umum Pusat Haji Adam Malik Medan periode Oktober 2016 hingga Maret 2017 terdiri dari 203 pasien COT ringan $(78,7 \%)$, kemudian 42 pasien COT sedang $(16,3 \%)$, dan 13 pasien COT berat (5\%). ${ }^{12}$ Pasien COT berat lebih sedikit dibandingkan dengan pasien COT ringan ataupun sedang dikarenakan kebanyakan pasien COT berat mengalami kematian ditempat kejadian sebelum ditransportasikan menuju rumah sakit, selain itu juga pasien dengan COT berat yang masuk IGD rumah sakit sering kali memiliki kondisi yang sudah sangat buruk, pasien banyak yang meninggal sebelum atau saat dilakukan tindakan resusitasi dan belum sempat dilakukan pemeriksaan lanjutan.

Mekanisme terbanyak yang terjadi adalah kecelakaan lalu lintas, terutama kecelakaan lalu lintas roda 2. Selain itu, didapatkan juga mekanisme penyebab lain pada penelitian ini yakni terjatuh. Hal ini sebanding dengan penelitian di Rumah Sakit Sentral Kamuzu Malawi pada periode Oktober 2016 hingga Mei 2017 terjadi COT dengan mekanisme penyebab terbanyak adalah kecelakaan lalu lintas yakni sebanyak $60,7 \% .^{13}$ Pada penelitian di IGD RS Bhayangkara Manado juga menyatakan bahwa mekanisme terbanyak adalah kecelakaan lalu lintas roda dua. ${ }^{14}$ Kecelakaan lalu lintas merupakan penyebab terbanyak terjadinya COT, dimana kecelakaan lalu lintas di jalan raya tidak didahului dengan gejala maupun pertanda apapun, dapat terjadi setiap waktu dan dapat terjadi dimana saja. Kecelakaan sering terjadi pada keadaan manusia yang bergerak dalam hal ini berlalu lintas yang hampir setiap saat dilakukan di kehidupan manusia. Kecelakaan lalu lintas terjadi karena keegoisan manusia seperti memotong jalan kendaraan tanpa haluan, memacu kecepatan kendaraan tanpa terkendali, dan melanggar rambu-rambu lalu lintas.

Terapi yang paling banyak didapatkan oleh pasien COT pada penelitian ini adalah terapi konservatif. Terapi COT sangat bergantung dari proses patofisiologi terjadinya COT itu sendiri. Terapi konservatif seperti terapi oksigen hiperbarik sering digunakan karena dipercaya memperbaiki gejala dan luaran kognitif pada pasien COT. Berbeda halnya dengan terapi operatif seperti kraniektomi dekompresif yang jarang dilakukan karena tingginya tingkat mortalitas, komplikasi, serta dipercaya dapat mengakibatkan kerusakan neuronal lanjutan. ${ }^{15}$ Dari hasil penelitian ini didapatkan bahwa pasien COT sekitar 54,2\% mengalami penurunan pada fungsi kognitif. Terdapat hubungan yang erat antara COT dengan penurunan fungsi kognitif. Mekanisme terjadinya penurunan fungsi kognitif diduga karena kerusakan sel-sel saraf, Diffuse Axonal Injury, perdarahan mikro, dan gangguan Blood Brain Barrier yang terjadi pada COT merupakan penyebab yang bersama-sama bisa mengakibatkan penurunan fungsi kognitif. ${ }^{3}$ Pada penelitiannya ini juga didapatkan bahwa penurunan kognitif menggunakan MMSE paling banyak pada atensi dan kalkulasi, serta orientasi. Penelitian di RSUP Prof. Dr. R. D. Kandou Manado juga menyatakan hal yang sama bahwa pada pemeriksaan MMSE pasien COT didapatkan kemunduran terbanyak terjadi terutama pada atensi dan kalkulasi. ${ }^{16}$

Mekanisme COT menjadi faktor yang menentukan dalam perubahan patologis otak. Pada cedera primer dapat terjadi hematoma intrakranial, DAI, dan kontusio. Sebagian besar pasien akibat kecelakaan lalu lintas 
dan sebagian kecil akibat jatuh. Kecelakaan lalu lintas menyebabkan terjadinya Diffuse Axonal Injury (DAI) tanpa adanya perdarahan intraserebral yang besar. Sebaliknya, jatuh sering menyebabkan hematom subdural dan intraserebral. Pada COT sekunder, faktor yang sering terjadi adalah hipertensi dan hipoksia. Rendahnya pasokan oksigen dibandingkan kebutuhan oksigen menyebabkan kaskade kerusakan iskemik sehingga menimbulkan influx ion $\mathrm{Ca} 2+\mathrm{ke}$ intraselular. Tingginya ion $\mathrm{Ca} 2+$ dalam sel akan menghentikan proses fosforilasi dalam mitokondria dan mencegah terbentuknya adenosine triphosphate (ATP). Penurunan produksi ATP ini mengakibatkan sel menjadi tidak berfungsi hingga terjadi kematian sel. Proses ini juga menyebabkan stres oksidatif. Segala perubahan inilah yang mengakibatkan selsel otak yang memiliki fungsinya masing-masing menjadi tidak berfungsi hingga mengalami kerusakan. Penurunan fungsi kognitif dapat terjadi apabila kerusakan sel-sel terjadi pada daerah-daerah tertentu pada otak yang mengatur fungsi kognitif itu sendiri. ${ }^{19}$

Penelitian ini hanya membuktikan hubungan tingkat keparahan COT menggunakan skor GCS dengan fungsi kogntif pasien menggunakan MMSE dan CDT. Terdapat penelitian lainnya yang menyatakan bahwa penurunan fungsi kognitif pada pasien COT tidak hanya dicerminkan oleh tingkat keparahan cedera saja tetapi juga bisa oleh tipe dan lokasi cedera. Seperti pada penelitian yang dilakukan oleh Guise et al yang menyatakan bahwa penurunan fungsi kognitif yang paling terlihat pada tipe cedera SAH, cedera bilateral otak, serta terdapat edema otak. Penurunan ini terlihat jelas pada CDT, pasien akan mengalami kesulitan dalam memproses integritas penggambaran jam serta kesulitan dalam penomoran jam. Pada penelitian ini juga menyatakan bahwa lesi di lobus parietal akan memperlihatkan penurunan fungsi kognitif yang sangat jelas terutama pada CDT. ${ }^{20}$

Keterbatasan dalam penelitian ini adalah tidak adanya pengelompokan pasien berdasarkan terapi guna menghomogenkan data terutama data hasil pemeriksaan fungsi kognitif. Selain itu, metodologi pengambilan data fungsi kognitif dilakukan satu kali saja pada waktu tertentu, sehingga tidak dapat melihat perkembangan fungsi kognitif pasien. Keterbatasan lain dari penelitian ini adalah adanya variabel-variabel yang belum terkontrol sehingga bisa mempengaruhi hasil penilaian fungsi kognitif pasien, seperti tingkat pendidikan pasien, jenis lesi, luas lesi, lokasi lesi, dan volume perdarahan pada lesi.

\section{Simpulan}

Pada analisis data menggunakan uji Chi-Square dengan tingkat kepercayaan 95\%, menunjukkan penurunan fungsi kognitif seiring dengan semakin beratnya COT $(p=0,000)$. Maka didapatkan kesimpulan dari penelitian ini, yakni terdapat hubungan bermakna antara skor GCS dengan fungsi kognitif pasien cedera otak traumatik di IGD RSUD Ulin Banjarmasin. Saran untuk penelitian ini adalah a. Perlu dilakukan penelitian lanjutan dengan pendekatan cohort, terutama untuk menilai perkembangan fungsi kognitif pasien; b. Perlu dilakukan penelitian dengan pengelompokan pasien berdasarkan letak lesi, jenis lesi, dan terapi agar data lebih homogen; c. Perlu dilakukan penelitian lanjutan untuk mengetahui hubungan fungsi kognitif dengan luaran pasien COT; d. Perlu dilakukan penelitian lanjutan untuk menilai keeratan hubungan menggunakan korelasi dari Pearson.

\section{Daftar Pustaka}

1. Badan Penelitian dan Pengembangan Kesehatan. Riset Kesehatan Dasar (RISKESDAS) 2013. Lap Nas. 2013:1-384.

2. Moppett IK. Traumatic brain injury: assessment, resuscitation and early management. BrJAnaesth. 2007;99(1):18-31.

3. Wang ML, Li WB. Cognitive impairment after traumatic brain injury: The role of MRI and possible pathological basis. J Neurol Sci. 2016;370:244-50.

4. Kennedy MRT, Wozniak JR, Muetzel RL, Mueller BA, Chiou HH, Pantekoek K, et al. 
White matter and neurocognitive changes in adults with chronic traumatic brain injury. $\mathrm{J}$ Int Neuropsychol Soc. 2009;15(1):130-36.

5. Krisandi E, Utomo W, Indriati G. Gambaran status kognitif pada pasien cedera kepala yang telah diizinkan pulang di RSUD Achmad Pekanbaru. Repositori Universitas Riau. 2013:1-8.

6. Majumder P, Khandelwal S, Sood M, Nehra A, Sharma B. A comparative study of cognitive function following traumatic brain injury: Significance of initial Glasgow coma scale score to predict cognitive outcome. J Ment Heal Hum Behav. 2015;20(2):59.

7. Ridha B, Rossor M. The mini mental state examination. Pract Neurol. 2005;5(5):298303.

8. Shulman KI, Pushkar GD, Cohen CA, Zucchero CA. Clock drawing and dementia in the community: A longitudinal study. Int J Geriatr Psychiatry. 1993;8(6):487-96.

9. Servadei F, Begliomini C, Gardini E, Giustini M, Taggi F, Kraus J. Effect of Italy's motorcycle helmet law on traumatic brain injuries. Inj Prev. 2003;9(3):257-60.

10. Manarisip MEI, Oley MC, Limpeleh $\mathrm{H}$. Gambaran CT scan kepala pada penderita cedera kepala ringan di BLU RSUP. Prof. Dr.R.D. Kandou Manado Periode 2012-2013. Jurnal e-CliniC (eCl). 2014;2:1-6.

11. Perhimpunan Dokter Spesialis Saraf Indonesia (PERDOSSI). Konsensus Nasional Penanganan Trauma Kapitis dan Trauma Spinal. 2006:1-18.

12. Sigalingging YE. Karakteristik cedera kepala di Rumah Sakit Umum Pusat Haji Adam Malik. Repositori Institusi Universitas Sumatera Utara (RI-USU). 2017:38-39.
13. Eaton J, Hanif AB, Grudziak J, Charles A. Epidemiology, management, and functional outcomes of traumatic brain injury in sub-Saharan Africa. World Neurosurg. 2017;108:650-55.

14. Habibie T, Bidjuni H, Malaria R. Hubungan cedera kepala dengan disorientasi pada pasien kecelakaan lalu lintas di IGD RS Bhayangkara. e-journal keperawatan. 2017;5(1):1-5.

15. Algattas H, Huang JH. Traumatic brain injury pathophysiology and treatments: early, intermediate, and late phases post-injury. Int J Mol Sci. 2013;15(1):309-41.

16. Athika N, Junita MJPS, Arthur HPM. Gambaran skor MMSE dan MoCA-INA pada pasien cedera kepala ringan dan sedang yang dirawat di RSUP Prof. Dr. R. D. Kandou Manado.Jurnale-CliniC(eCl).2016;4(1):1-8.

17. Lee CN, Koh Y-C, Moon CT, Park DS, Song SW. Serial mini-mental status examination to evaluate cognitive outcome in patients with traumatic brain injury. Korean J Neurotrauma. 2015;11(1):6-10.

18. De Guise E, Gosselin N, Leblanc J, Champoux MC, Couturier C, Lamoureux J, et al. Clock drawing and mini-mental state examination in patients with traumatic brain injury. Appl Neuropsychol. 2011;18(3):179-90.

19. Abdul-Muneer PM, Chandra N, Haorah J. Interactions of oxidative stress and neurovascular inflammation in the pathogenesis of traumatic brain injury. Mol Neurobiol. 2015;51(3):966-79.

20. De Guise E, Leblanc J, Gosselin N, Marcoux J, Champoux MC, Couturier C, et al. Neuroanatomical correlates of the clock drawing test in patients with traumatic brain injury. Brain Inj. 2010;24(13-14):1568-74. 